\title{
EFFECTS OF CASTRATION ON MEAT QUALITY AND ECONOMY OF FATTENING
}

\begin{abstract}
$\mathrm{C}^{\mathrm{a}}$ ONTROVERSY about the value of castration to improve the value of domestie animals for different purposes is not new. Not so very long ago stallions were used in the cavalry, with diastrous results on parade and elsewhere. In the East there is strong belief that entire male animals can do more physical work than castrates. The increased docility of castrates for most types of animal husbandry has led in developed countries to almost universal castration of male animals, with the general belief that, even if only from the economic point of view, it is a success. As to one phase of the subject, the effect on the flavour and general quality of the flesh, there has been some difficulty. In the absence of satisfactory tests to determine these points, general economical eriteria have been used to provide answers about the effects of the generative organs on the body.

On another phase of the subject, cruelty involved, there is a grave indictment of mankind. Relatively few countries have legislation about the operation of castration. In large parts of the world the grossest cruelty over this operation is routine. The technique known as bisturnage, manipulation of the testicle within the unopened scrotum to twist the spermatic cord and so cause atrophy of the organ, must be very painful even when skilfully done and it is not always successful in practice. The even more brutal method of hammering the testicle with a kind of mallet over a solid base done on a wide scale in the East is far from being a success; in unskilled, careless hands the pain is up to schedule, but the testicle is not always destroyed. These methods may have developed because of serious complications in pre-surgical times from removal by the knife, or even the hot iron-complicating infections, or even death from tetanus or other germs.

Two important communications about the effects of castration on farm food animals merit attention, in that they lend support to moves in certain countries for the fattening for the butcher of entire male animals, instead of previous castration.

J. D. Turtin has recently reviewed the current literature on "The Effect of Castration on Mest Production and Quality in Cattle, Sheep and Pigs" (Animal Breeding Abstracts, 30, 447; 1962). Much consideration will be required before wide changes in existing practices can be made. These concern prices of the finished animal for sale to the butcher, matters relating to qualities, legal enactments, as well as the general economics of fattening for the butcher. The matters discussed here are important
\end{abstract}

and indicate the need for research on all aspects of the subjoct. Turtin quotes production data for sheep, cattle and pigs from the publications dealt with and he says, "Reviewing the results on pigs of growth rate, efficiency of conversion and carcass quality as a whole, it does not seem that there is sufficient experimental evidence to support a break with the traditional practice of castration although, as with sheep, an authoritative evaluation from an economical standpoint has yet to be carried out". The evidence with cattle slaughtered at 12-15 months suggests that entire animals fatten more cheaply.

A recent communication by A. A. Baiburtjcan, translated from the Russian by G. R. Ritchie, suggests "A New Method of Increasing the Productivity of Livestock (by Partial Castration)" (Animal Breeding Abstracts, 31, 1; 1963). The author deals with the subject at length and many parts are merely mentioned in the translation by title of chapters, without details of the text. This, however, does not hinder discussion on his main thesis as sufficient detail is given of the main argument. The subject is dealt with under: age when done; techniques that have been used; a detailed description of technique advocated for a new method of castration by which the spermatogenie function is inhibited and the hormonal function retained; economic and surgical effectiveness of various methods of castration; effects of various methods on carcass yield; effects on chemical composition of meat and fat; histology; on internal secretions.

Tables show carcass characteristics of ram lambs castrated by different methods and killed when three or four months old; body weights of young bulls castrated by different mothods and killed at intervals from one to four months later; live and earcass weights of boars on high and on average planes of nutrition; chemical composition of carcass elements after different methods of castration; weights of genitalia of pigs and sheep after different methods of castration.

Baiburtjean bases his theories about the advantages of "partial castration" on the belief that, by this technique, most of the testicular tissue is removed,yet sufficient regeneration can occur, within the necessary intervals, for internal secretions to operate mutually with the epididymes to control carcass development; that the operation prevents the troublesome habits of entire animals towards the end of the fattening process as sexual development intervenes.
W. POOL

\section{TRYPTAMINE RECEPTORS IN THE CENTRAL NERVOUS SYSTEM: EFFECTS OF AN/ESTHETICS}

\author{
By DR. E. MARLEY \\ Institute of Psychiatry, Maudsley Hospital, London, S.E.5 \\ AND \\ DR. J. R. VANE \\ Department of Pharmacology, Royal College of Surgeons of England, London, W.C.2
}

RYPTAMINES have several actions on receptors
in the central nervous system ${ }^{1,2}$, including facilitation
of spinal reflexes. In the experiments of Vane et al. ${ }^{2}$,
tryptamine and $\alpha$-methyltryptamine produced such
facilitation in spinal and in chloralosed cats. Recently,
Curtis ${ }^{3}$ concluded that spinal neurones were not affected
by tryptamine and $\alpha$-methyltryptamine since, when they were applied electrophoretically, he was unable to show any change in extracellular potentials. Since Curtis ${ }^{3}$ used cats anæsthetized with pentobarbitone we have tested whether the differences in results can be explained by the effects of anæesthetics.

Anrsthesia was induced with ethyl chloride and ether. The trachea was cannulated, and the cat was artificially 